\title{
pengertian dan proses administrasi peserta didik
}

\author{
Melia Sri Devi1, hade afriansyah2 \\ 1Universitas Negeri Padang, Padang, Indonesia (meliasridevi@gmail.com) \\ 2Universitas Negeri Padang, Padang, Indonesia, (hadeafriansyah@fip.unp.ac.id)
}

\section{A. Pengertian Administrasi Peserta Didik}

Administrasi

peserta didik merupakan kegiatan pencatatan murid dari proses penerimaan hingga murid tamat dari sekolah atau keluar karena pindah sekolah atau sebab lain.

Nah teman-teman ingat tidak ketika masuk skolah pasti banyak berkas-berkas yang dikumpulkan ke sekolah, nah itu merupakan salah satu cara guru untuk melengkapi administrasi perserta didik nya.

\section{B. Proses Administrasi Peserta Didik}

Proses ini dibagi menjadi tiga tahapan yaitu Administrasi pada awal tahun pelajaran, Setahun pelajaran, dan Akhir tahun pelajaran. Mari kita bahas satu persatu teman-teman.

1. Adminitrasi pada awal tahun pelajaran.

\section{Yaitu}

melaksanakan penerimaan murid baru. Penerimaan murid adalah proses seleksi dan pencatatan murid yang memasuki sekolah tertentu dan memenuhi persyaratan-persyaratan yang ditentukan oleh sekolah itu sendiri. Untuk Administrasinya tidak usah saya sebutkan, teman-teman pasti sudah tahu apa-apa saja administrasi yang harus dikumpulkan ketika masuk sekolah baru.

2. Administrasi setahun pelajaran

$$
\text { yaitu membina }
$$

murid tersebut sehingga berkembang kemampuannya secara maksimal sesuai dengan tujuan sekolah. Pembinaan murid dilakukan agar murid mengenal lingkungan tempat belajar mereka dan dapat menyesuaikan diri dengan tuntunan sekolah. Nah setahun pelajaran inilah siswa di didik disiplin peraturan sekolah dan belajar apa yang tidak ia ketahui menjadi tahu, dari yang tidak bisa menjadi bisa.

ex :

Ketika masuk sekolah murid harus datag jam 7 pagi dan taati peraturan yang berlaku, jika melanggar maka akan ada sanksinya (melatih disiplin).

Ketika masuk SD kita tidak bisa membaca sama sekali, kalaupun 
bisa masih terbata-bata, belum lancar. Nah guru membimbing agar bisa membaca dengan lancar dan benar, disini guru telah melakukan proses pembelajaran dan melengkapai Administrasikan seperti absensi, buku nilai, dll (perkembangan kemampuan).

3. Administrasi Akhir Pembelajaran

$$
\text { yaitu pengisian }
$$

rapor murid selama belajar dalam satu tahun. Nah penilaian akhir pembelajaran ini sangat penting untuk murid agar bisa naik tinggkat yang lebih tinggi.

\section{Peran guru dalam administrasi peserta didik}

1. Guru dapat dilibatkan dalam penerimaan murid baru dengan mamasukkannya dalam

kepanitiaan penerimaan murid baru.

2. Membuat murid beradaptasi dengan cepat pada lingkungan sekolahnya.

3. Mengontrol kehadiran anak dengan buku absensi murid.

4. Memotivasi murid

5. Menciptakan disiplin kelas yang baik. 